the early depersonalization of available ideas of a supreme being and their lack of ideas of creativity, all prevented the development of the conception of the laws of Nature from Chinese conceptions of law in general. Moreover, the concrete forces of Chinese social and economic life were not sufficiently favourable to science to overcome such inhibiting factors.

Traditional Colonial Art: Exhibition at the Imperial Institute, London

AN exhibition of traditional Colonial art has been arranged in the Art Gallery of the Imperial Institute, South Kensington, London, S.W.7, and will be open to the public until September 30 (weekdays, 10 a.m.-6 p.m.; Sundays, 2.30 p.m.-6 p.m.). The exhibition presents only work from Colonial territories of the British Commonwealth which is authentically traditional, thus excluding curticles made for export or for sale to the tourist and such modern work as is produced under external influence; the selection of the work displayed has been governed by westhetic considerations, and the exhibition is not planned as an ethnographical or anthropological study. The exhibition is divided into two sections, the larger being devoted to sculpture, and the smaller to such crafts as pottery, basketwork, textiles and other forms of cloth, metalwork, etc.

\section{Commonwealth Fund Fellowships}

CommonweaItH Fund fellowships, tenable by British graduates in American universities for one year beginning in September, have been awarded to the following, among others: A. C. Allen, Queen's University, Belfast, and Peterhouse, Cambridge (mathematies); H. Davies, Jesus and Merton Colleges, Oxford (theoretical physics) ; M. W. Dick, Balliol College, Oxford (symbolic logic); M. J. Farrell, New College, Oxford, and King's College, Cambridge (economics) ; R. P. Jepson, University of Manchester (experimental surgery); M. S. Longuet-Higgins, Trinity College, Cambridge (oceanography); W. S. Owon, University of Liverpool (motallurgy); K. V. Roberts, King's College, Cam bridge (theoretical physics); O. Smithies, Balliol College, Oxford (physical chemistry); B. A. D Stocker, University of London (bacteriology) ; L. E. Weiss, University of Birmingham (geology). Dominion and Colonial Civil Service Fellowships of the Commonwealth Fund, tenable by Civil servants from the British Commonwealth, have been awarded to the following, among others, for study in the United States (not necessarily at a university): E. W. de Lisle, Now Zealand (radio engineering); W. J. Gibbs, Australia (meteorology); K. G. E. Moody, Australia (civil engineering); C. H. de C. Murray, South Africa (psychology); S. F. Barnett, East Africa (veterinary science); S. Woolmer, Singapore (town planning).

\section{University of London}

Prof. P. B. MEdawar, Mason professor of zoology in the University of Birmingham, has been appointed to the Jodrell chair of zoology and comparative anatomy tenable at University College, London, as from October 1, in succession to Prof. D. M. S. Watson. The title of reader in anthropology in the University has been conferred on Dr. Phyllis Kaberry, in respect of the post held by her at University College. The following doctorates have been conferred: D.Sc. : Mr. L. B. Holt (University College), Mr. R. A. M.
Mackay (Imperial College of Science and Technology); D.Sc.(Eng.): Mr. Guthlac Wilson (Queen Mary College).

\section{Society for Endocrinology: Officers}

OFFICERS and the committee of the Society for Endocrinology have been elected as follows: Chairman, Dr. S. J. Folley; Honorary Secretaries, Prof. C. H. Gray and Prof. N. F. Maclagan; Honorary Treasurer, Dr. F. L. Warren ; Honorary Editor of the Society's Proceedings, Dr. P. L. Krohn; Ordinary Members of Committee, Prof. E. C. Amoroso, Dr. G. W. Harris, Dr. C. J. O. R. Morris and Dr. E. F. Seowen. Communications should be sent to the Honorary Secretary of the Society, Department of Chemical Pathology, King's College Hospital, Denmark Hill, London, S.E.5.

\section{Society for General Microbiology}

OFFICERS for 1951-52 of the Society for Genera] Microbiology have been elected as follows : President, Prof. J. W. McLeod; Meetings Secretary, Dr. W. E. van Heyningen; General Secretary, Dr. J. G. Davis ; T'reasurer, Dr. R. Lovell; Editors, Prof. B. C. J. G. Knight and Mr. A. F. B. Standfast. The Society, which was founded in 1945, now has 985 members and will hold its September meeting in Manchester. Further information about the Society can be obtained from Dr. J. G. Davies, 35 Villiers Road, Southall, Middlesex.

\section{"Biology in "Chambers's Encyclopædia" "}

IN a review under this title published in Nature of April 21, reference was made to the point that, going through the sections letter by letter, certain topics were not found at the points expected. Mrs. M. D. Law, managing editor of the "Encyclopædia", states that, in fact, there is a section on biochemistry, by Prof. E. H. F. Baldwin, under 'B', and a paragraph on Canada balsam under 'C'; both were unfortunately overlooked by the reviewer. As regards the other comments on omissions under appropriate letters, Mirs. Law points out each one is dealt with at some point in the work, and can readily be found by reference to the general subject index in vol. 15, which is designed to guide readers to the heading including the topic under discussion.

\section{A Giant Sunspot}

THE big sunspot reported in Nature of April 28 (p. 672) returned with renewed development to cross the sun's disk during May 9-22. When fully in view near the sun's east limb, the area of this complex group corrected for foreshortening was about 2,250 millionths of the sun's hemisphere, and by the time it had passed the sun's central meridian on May 16.0 U.T. the area had increased to 4,850 units, or about 110 times the cross-section area of the earth. A peak area of this value has been exceeded by only two other spot groups, and equalled by a third, in the photographic record of sunspots maintained by the Royal Greenwich Observatory since 1874. All these spots have occurred in the present 11-year sunspot cycle and appeared successively in February 1946, July 1946 and April 1947, the last attaining the remarkable area of more than 6,000 millionths. The first two groups were associated with intense solar flares followed by 'great' geomagnetic storms, in the first case $17 \frac{1}{2}$ hours, and, in the second, $26 \frac{1}{2}$ hours after the flares. The present spot showed little 